UDC 81.112.2

DOI https://doi.org/10.24919/2308-4863/35-6-21

Liudmyla SHEREMETA,

orcid.org/0000-0001-6567-0484

Candidate of Pedagogical Sciences, Associate Professor, Associate Professor at the Department of Ukrainian Language Ivan Horbachevsky Ternopil National Medical University of the Ministry of Health of Ukraine (Ternopil, Ukraine) sheremeta@tdmu.edu.ua

\title{
CONCEPTS OF TERMINOLOGY, TERMINOLOGY STUDIES, THE TERM SYSTEM AND THE TERM
}

It was made the historical-linguistic study of the formation and development of medical terminology of a professionally oriented language, the basis of which is a special vocabulary that nominates a certain set of concepts and is used in a particular science. Its significance for medical science is determined, the versatility of which generates a large amount of knowledge and requires professional mastery of the language of the specialty - a set of language tools which are used to achieve understanding in a professionally limited field of communication.

The main stages of formation of medical terminology, which are based on the analysis of the scientific literature, are outlined. It has been established that the concept of "terminology" as a branch of science is associated with the name of Eugene Wuster, who laid the foundations of the science of terms. It is proved that in the 30s of the XX century at the junction of linguistics, logic, computer science, psychology and other sciences stood out terminology as a modern science, the main subject of which is to cover the interaction of terms with literary vocabulary, the basic concepts of terms science, classification of terms, study of their structural-semantic and grammatical features, sources of origin, as well as methods of translation from one language to another which means standardization of terms.

The concepts of "terminology", "terminology" and "term" are distinguished. Terminology is understood to be the whole set of terms such as linguistic units, united by logical-conceptual connections that reflect the relations that have objectively developed in the relevant field and serve the field of knowledge related to a particular system of concepts. Terminology is the source of terminological systems, but, unlike terminology, the terminological system is formed not together with the formation of a particular science, but according to the stages of formation of the theory or theories of this science. A terminology system is a system of terms in a particular field of scientific or technical knowledge that serves a scientific theory or scientific concept. The basis of any terminology system, as well as terminology, is a term - a word or phrase that is an organic (systemic or non-systemic) element of the terminological register and denotes a certain concept in a particular field of human activity.

Key words: terminology, terminology, terminology, term, medical terminology.

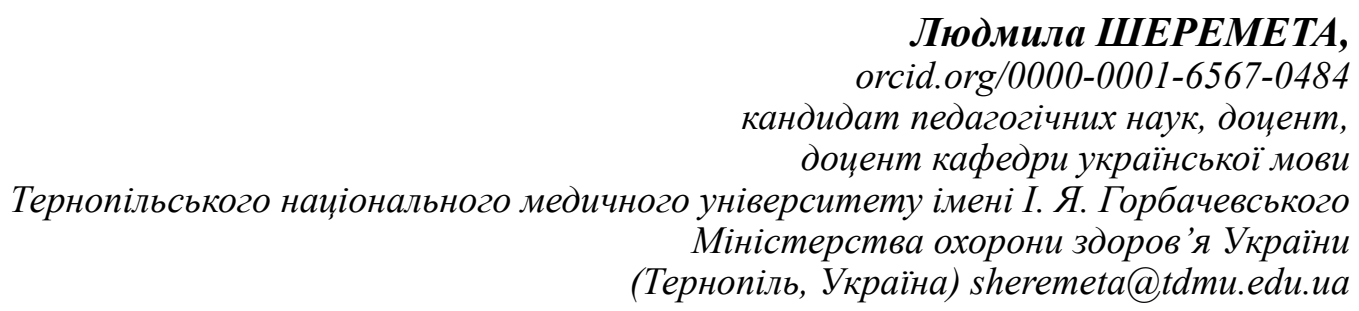

\section{ПОНЯТТЯ ПРО ТЕРМІНОЗНАВСТВО, ТЕРМІНОЛОГІЮ, TEPMIНОСИСТЕМУ ТА ТЕРМIH}

\footnotetext{
Здійснено історико-лінгвістичне дослідження становлення та розвитку медичної термінологї- професійно орієнтованої мови, основою якої є спечіальна лексика, яка номінує певний комплекс понять $i$ застосовується $в$ конкретній науці. Визначено ї̈ значення для медичної науки, багатогранність якої породжує велику кількість знань і вимагає професійного оволодіння мовою відповідної спеціальності - сукупністю мовних засобів, які використовуються для досягнення порозуміння у професійно обмеженій сфері спілкування.

На основі аналізу наукової літератури окреслено основні етапи становлення медичної термінології. Встановлено, шуо поняття термінології як галузі науки пов'язане з іменем Ойгена Вюстера, який $і$ заклав основи науки про терміни. Доведено, щуо у 30-х роках ХХ століття на стику лінгвістики, логіки, інформатики, психологї та інших наук виокремилося термінознавство як сучасна наука, основним предметом якого є висвітлення питання взаємодії термінів із літературною лексикою, проблематика основних понять науки про терміни, класифікація термінів, вивчення їх структурно-семантичних і граматичних особливостей, джерел походження, а також методики перекладу з однісї мови на іншу, тобто стандартизації термінів.
} 
Розмежовано поняття «термінологія», «терміносистема» та «термін». Під термінологією розуміють усю сукупність термінів як мовних одиниць, об'єднаних логіко-поняттєвими зв'язками, щзо відображають відношення, які об'єктивно склались у відповідній галузі і обслуговують сферу знань, пов'язаних із певною системою понять. Термінологї є джерелами терміносистем, але, на відміну від термінології, терміносистема формується не разом із формуванням певної науки, а відповідно до етапів формування теорії або теорій иієі науки. Терміносистема - ие система термінів у певній галузі наукового або технічного знання, щзо обслуговує наукову теорію або наукову концепцію. Основною будь-якої терміносистеми, як і термінологїі, є термін - слово або словосполучення, яке є органічним (системним чи позасистемним) елементом термінологічного реєстру $i$ позначає певне поняття в тій чи іншій галузі людської діяльності.

Ключові слова: термінознавство, термінологія, терміносистема, термін, медична терміносистема.

Formulation of the problem. Scientific terminology in any field plays an important role because it reflects certain concepts in the system of names used in a particular science. It is of particular importance for medical science, the versatility of which generates a great deal of knowledge and requires professional mastery of the language in the relevant specialty i.e. a set of linguistic means used to achieve understanding in a professionally limited field of communication.

Modern medicine is used in a properly organized professionally oriented language, the basis of which is a special vocabulary. Professional language is a natural environment for the emergence and functioning of terms that name a complex of medical concepts and are considered as its central components. In fact, it is the term systems (terminology) that form the basis of a doctor's professional language. As a consequence, the main task of medical educational institutions is to prepare highly qualified medical specialists, which provides for their terminological training not only within the meaning of terms, but also the ability to professionally use them professionally or in a practical or scientific activity, both verbally and in writing. This is due to the fact that the term occupies an important place in all stages of medical education, as it serves as a tool of cognition and a means of fixing its result.

In the context of modern global and international communication, a graduate of a medical educational institution have to possess not only professional knowledge and skills that meet international standards, but also to be intellectually developed person, familiar with the cultural and scientific heritage of the mankind, especially in the sphere of medicine and medical service. It is a good idea that "nowadays any Ukrainian doctor traditionally uses the Ukrainian medical terms, the terms of Greek and Latin origin, and the terms from Western Europe that appeared with the emergence of new directions and branches of science ..., as well as Latin terms which form the basis of the International Nomenclature and mostly lacked their native languages" (1931).

The aim of research: to reveal the role of medical terminology in the context of the current linguistic situation.
Presentation main material. In foreign linguistics the first attempts to analyze medical terminology have their own history. Thus, in the eighteenth century all diseases, diagnoses, data of operations and treatment were systematically classified; there were also reports of patient care with different levels of details (referring to John Grant's "London Mortality Accounts", François Bossier de Lacroix's "Nosologia methodica", Linnaeus' "Genera morborum", William Cullen's "Synopsis nosologiae").

The very concept of "terminology" as a branch of science is associated with the name of Eugene Wooster, who wrote his doctoral thesis "International normalization of speech in engineering and electronics" in 1931. In this work he laid the foundations of the science of terms. Based on the provisions of this work, the International Terminology Committee is still in force. The scientist himself became the founder of the Vienna School of Terminology (in the history of terminology it is also known Moscow, Leningrad and Prague School of Terminology). Eugene Wüster believed that giving preference to the Greek and Latin bases in the allocation of terms from the lexical sphere of the national language was important in the process of termination (the concept, from which the term originates, remained important. H. Felber, who is the author of the first international textbook on terminology "Terminology Manual", continued his work (1984).

It was the time when the work of D.C. Lotte (a founder of the Moscow Terminology School) appeared. It was dedicated to the selection and standardization of terms. The work had a monographic character and was intended for specialists in various fields of science and technology, because "the development and mass mastery of technical knowledge required the correct, uniform and clear terminology" (1961). The merit of scientists of the Moscow Terminology School, particularly of S. A. Chaplygin, E. K. Dresin, G. O. Vinokur, is an attempt to identify the problems of terminology and its main tasks i.e. the foundations of terminological theory and practice, and therefore the basic principles of terminology as a science. 
In the second half of the twentieth century, the Leningrad Terminology school appeared, which was engaged in:

- the issues of historical terminology (L. L. Kutina, F. P. Sorokoletov, Sh. D. Konovalov);

- the publication of the first textbooks on terminology (A. D. Khayutin "Term, terminology, nomenclature" (1972), A. S. Akhmanov "Terminology: Theory and Method" (1977);

- the isolation of a number of terms varieties (general and special, own and borrowed, terms of language and terms of speech, theoretical and empirical, pseudo terms) and the main areas of terminology in the form of independent disciplines, such as: terminography, term processing, specific terminology).

The merit of the Prague Terminology School (the most famous representative was L. Drozd) is a structural and functional description of special terminology systems, standardization of special languages and terms.

The study of scientific literature on terminology makes it possible to state that in the 1930s, at the intersection of linguistics, logic, informatics, psychology and other sciences, terminology stood out as a modern science: the issues of interaction of terms with literary vocabulary were being researched; the problems of terminology were formed; terms were classified, their structural-semantic and grammatical features were studied; the sources of their origin, the method of translation from one language to another was developed; however, the issue of terms standardization, cognitive aspects of their study remained important.

The main category in terminology is the concept of "term". There are also other sets of linguistic units called "terminology" and "term system". These unities are also the subject of research in terminology. Thus, terminology study is "a science that studies the terms, terminologies and term systems, the laws of their creation and functioning" (Суперанская, 1989: 12).

In linguistics the concepts of "terminology" and "term system" are also distinguished.

Terminology means the whole "set of terms as linguistic units, united by logical and conceptual connections, reflecting relations that are objectively formed in the relevant field, and serving the sphere of knowledge related to its system of concepts" (Українська мова за професійним спрямуванням, 2017: 62). Typical for formulating the terminology of a particular industry is borrowing terms or whole terminology. Terminology is the source of term systems, but, unlike terminology, term systems are formed not in conjunction with the formation of a particular sci- ence, but according to the stages of formation of the theory or theories of this science.

Understanding the terminology as an independent science is an achievement of the present. For a long time it was interpreted as:

- "a set of terms of any industry" (Толковый словарь русского языка, 1940);

- "a set of terms used in a particular field of science, e.g. technology, politics, arts” (Энциклопедический словарь, 1955);

- "a part of vocabulary, covering terms of various branches of science, technology, art, public life; a set of terms of any branch of science, technology, art, etc. or all terms of a given language" (Українська радянська енциклопедія, 1960).

Having analyzed the basic definitions of terminology as a science, we can say that in the "Ukrainian Soviet Encyclopedia" we see an attempt to look at the terminology as a detailed classification of linguistic units (Нікітіна, 1978: 12) whereas T. R. Kyyak distinguishes terminology as an arbitrary set of terminological units and term system as their systematically ordered combination. The reason for this distinction is that a large number of terms arise spontaneously and do not enter into the terminological hierarchy as its organic component. The closest understanding of terminology as an independent science is described in the works of B. N. Holovin and A. V. Saperans'ka, where terminology is regarded as a science of terms. As you can see, the terminology is interpreted as: 1) a set of the terms in science, technology, culture, art, etc.; 2) section of linguistics; 3 ) the doctrine of terms. In order to differentiate the concepts of the doctrine of terms and the science of terms, the first is advisable to use the phrase "term studies", and the second - "terminology".

Thus, terminology, like every branch of science, has its own subject of study, basic principles and methods of research, the procedure for the description and analysis of the material under study and the practical implementation of theoretical provisions of the field.

Terminology is the source of the term system. We agree with the opinion of O. S. Petryna, however, that "we see the difference between terminology and the term system in that the terminology is a set of lexical units that is formed gradually according to the stages of formation of the scientific-professional branch, whereas the term system is a hierarchical system of terms arranged by the terminological terminology" (Петрина, 2018: 64).

Term system as a model of a particular branch of knowledge or activity, unlike terminology, is formed not in conjunction with the emergence of a particular science, but in accordance with the stages of formation of the theory of science; there may be several 
term systems in the same sphere according to certain theories. Ya. V. Zhytin states that the term system is not tied to a particular science but to a particular theory. R. I. Dudok defines the term system as "the system of terms of a particular science or technology. In other words, it is a set of terms that provide the nomination of the main concepts of a certain sphere of knowledge and activity, connected with each other logically-semantic and other relations" (Дудок, 2009: 184). V. M. Leychyk emphasizes the deliberate ordering or construction of term systems from natural but specially selected units, which are considered to be complete terms (Лейчик, 2001: 54). This opinion is shared by L. A. Manerko who stated that the term system is "a deliberately constructed set of terms based on categorical and conceptualized information, as well as on the basis of logically-conceptual, cognitive-linguistic, discursive and proper terminological requirements" (Манерко, 2009: 207). Therefore, a term system is a system of terms in a particular field of scientific or technical knowledge that serves a scientific theory or scientific concept.

The basis of any term system, like terminology, is the term. For a long time in linguistics its definition has been interpreted in different ways, although nowadays it does not have a single definition. In its development, the term "term" was defined as:

- "a word that denotes a clearly defined philosophical, scientific, technical, etc. concept” (Энциклопедический словарь, 1955);

- "a word or a phrase of a special (scientific, technical, etc.) language that is created, received or borrowed for the exact expression of special concepts and designation of special subjects" (Ахманова, 1966: 95-96);

- "a word or a phrase that expresses a specific concept of any branch of science, technology, art, public life, etc.” (Українська радянська енциклопедія, 1960).

At the end of the twentieth century, many definitions of the term "term" appeared. These include those that characterize the term as:

- "a word or a verbal complex that correlates with the notion of a particular organized field of cognition (science, technology) and enters into a systemic relationship with other words and verbal complexes, forming with them in each individual case and at certain times a closed system characterized by high informative, unambiguous, accurate and expressive neutrality" (Квітко, 1976: 21);

- "a basic unit of the terminological system what determines its structure and specificity of features that distinguishes this system unit from others" (Нікітіна, 1978: 3).
These definitions can be considered the most successful among those which are well-known in linguistics. There are many generic concepts by which researchers define the term: a verbal complex; a special object; a special concept; a language sign; a word; a special word; a verbal complex motivated sign; lexicalized communication; an abbreviation; a function; an element of the term system; a unity of sign and concept; a lexical unit. Nevertheless, none of the modern definitions can completely satisfy the scientists. The presence of so many understandings and definitions of the term "term" confirms the impossibility of creating a universal definition. So, by summarizing and clarifying the above definitions, you can give the following definition of the term "term" - (from the Greek $\tau \varepsilon \dot{\rho} \mu \mu \alpha$ 'end, border') - a word or phrase that denotes a certain concept in a particular field of human activity e.g. science, technology, culture, sports, art, etc. This understanding of the term is rooted in traditional linguistics, which regards the term as a word or phrase, which is an organic (systemic or extra-systematic) element of the terminological register and denotes a certain concept in a particular field of human activity.

Conclusions. It is well known that the basic function of an industry term is to express scientific concepts precisely and concisely. In addition, the term should be characterized by monosemy and be a means of its identity and distinction in a special language. For the successful implementation of this function, the term - as the unity of form and content - must meet the following important requirements:

1. Accuracy: a) the content (meaning or semantics) of the term must be strictly (unambiguously) different from other concepts in the relevant microsystem; b) the sound system must not contain elements that may disorientate the content and scope of the scientific concept.

2. Identity (correspondence): the meaning of the term must correspond to the current scientific knowledge of the subject, phenomenon, process, feature, etc.

3. Conciseness, in accordance with the notion.

4. Monosemy i.e. any sound complex must be secured by one scientific concept.

5. Invariance as lack of variants and synonyms.

6. Uniform design: the term-word must be expressed in one sound formula.

7. Conventionality, that is, identical features of concepts must be denoted in different terms by the same linguistic signs (words, phrases, abbreviations, term elements).

8. Compliance with the rules of the language, which prevents the appearance of jargon. 
9. Availability of classification definition.

10. Sound complexes expressing the same concepts should be built on a common (single) structuralsemantic model.

11. Stylistic neutrality, that is, deprivation of expressive coloring.
12. Transparency of the internal form of the term.

13. High informativeness.

However, these requirements remain more declared than practically implemented, rather ideal, than actually fulfilled within certain micro term systems.

\section{BIBLIOGRAPHY}

1. Ахманова О. С. Словарь лингвистических терминов. Москва : Советская энциклопедия, 1966. 607 с.

2. Головин Б.Н. Основы культуры речи. Москва : Высшая школа, 1988. 320 с.

3. Дудок Р. І. Проблема значення та смислу терміна в гуманітарних науках : монографія. Львів : Видавничий центр НУ ім. Івана Франка, 2009. 358 с.

4. Квітко І. С. Термін у науковому документі. Львів : Вища школа, 1976. 125 с.

5. Лейчик В. М. Проблема системности в отечественном терминоведении. Научно-техническая терминология : научно-реф. сборник. 2001. Вып. 20. С. 54-55.

6. Манерко Л. А. Понятие «терминосистема» в современном терминоведении. Современные тенденции в лексикологии, терминологии и теории LSP (сборник научных трудов). Москва : Изд-во МГОУ, 2009. С. $207-220$.

7. Нікітіна Ф. О. Семантичні та словотворчі проблеми сучасної термінології : навч. посібник. Київ : Вища школа, 1978. $32 \mathrm{c}$.

8. Німчук В. В. Мова українського травника XVI ст. Мовознавство. 1976. С. 43-55.

9. Петрина О. С. Провідні характеристики термінології та терміносистеми. Science and Education a New Dimension. Philology, 2018. VI(51). Issue: 176. C. 62-65.

10. Пиріг Л. А. Українська мова і термінологія як засіб спілкування українського лікаря. Актуальні проблеми медичної термінології. Львів, 1993. С. 19.

11. Суперанская А. В. Общая терминология : Вопросы теории. Москва : Наука, 1989. 246 с.

12. Термінологія у професійному спілкуванні. Лексико-семантичні відношення в наукові термінології. Особливості української медичної термінології. Матеріали для підготовки до заняття. URL: https://moodle.tdmu.edu.ua/mod/ resource/view.php?id=171784

13. Толковый словарь русского языка. Москва : Гос. изд-во иностранных и национальных словарей, 1940. T. IV. $1501 \mathrm{c}$.

14. Українська мова за професійним спрямуванням : підручник для мед. ВНЗ. Київ, 2017. 360 с.

15. Українська радянська енциклопедія. Київ : Гол. ред. УРЕ, 1959-1965. Т. 1-17.

16. Энциклопедический словарь. Москва : Гос. науч. изд-во «Большая советская энциклопедия», 1955. Т. 3. 744 с.

\section{REFERENCES}

1. Akhmanova O. S. Slovar lynhvystycheskykh termynov [Dictionary of linguistic terms]. Moscow: Soviet Encyclopedia, 1966. 607 p. [in Russian].

2. Holovyn B. N. Osnovu kulturu rechy [Basics of language culture]. Moscow: High School, 1988. 320 p. [in Russian].

3. Dudok R. I. Problema znachennia ta smyslu termina v humanitarnykh naukakh [The problem of meaning and meaning of the term in the humanities [monograph]]. Lviv: NU Publishing Center: Ivan Franko. 2009. 358 p. [in Russian].

4. Kvitko I. S. Termin u naukovomu dokumenti [Term in a scientific document]. Lviv: Higher school. 1976. 125 p. [in Ukrainian].

5. Leichyk V. M. Problema systemnosty v otechestvennom termynovedenyy [The problem of consistency in Russian terminology]. Scientific and technical terminology: scientific ref. collection. Issue 20. 2001. P. 54-55 [in Russian].

6. Manerko L. A. Poniatye «termynosystema» v sovremennom termynovedenyy [The concept of «terminology» in modern terminology]. Modern trends in lexicology, terminology and theory of LSP (collection of scientific papers). Moscow: Publishing house of MGOU. 2009. P. 207-220 [in Russian].

7. Nikitina F. O. Semantychni ta slovotvorchi problemy suchasnoi terminolohii: [navch. posibnyk] [Semantic and wordformation problems of modern terminology: [textbook manual]]. Kyiv: Higher school. 1978. 32 p. [in Ukrainian].

8. Nimchuk V. V. Mova ukrainskoho travnyka XVI st. [The language of the Ukrainian herbalist of the 16 th century]. Linguistics. 1976. P. 43-55 [in Ukrainian].

9. Petryna O. S. Providni kharakterystyky terminolohii ta terminosystemy [Leading characteristics of terminology and terminology]. Science and Education a New Dimension. Philology. VI(51). Issue: 176. 2018. P. 62-65 [in Ukrainian].

10. Pyrih L. A. Ukrainska mova i terminolohiia yak zasib spilkuvannia ukrainskoho likaria [Ukrainian language and terminology as a means of communication of a Ukrainian doctor]. Current issues of medical terminology. Lviv. 1993. P. 19 [in Ukrainian].

11. Superanskaia A. V. Obshchaia termynolohyia [General terminology: Questions of theory]. Moscow: Science. 1989. 246 p. [in Russian].

12. Terminolohiia u profesiinomu spilkuvanni. Leksyko-semantychni vidnoshennia $\mathrm{v}$ naukovi terminolohii. Osoblyvosti ukrainskoi medychnoi terminolohii [Terminology in professional communication. Lexical-semantic relations in scientific terminology. Features of Ukrainian medical terminology]. Materials for preparation for the lesson. Access mode: https://moodle.tdmu.edu.ua/mod/resource/view.php?id=171784 [in Ukrainian]. 
Sheremeta L. Concepts of terminology, terminology studies, the term system and the term

13. Tolkovui slovar russkoho yazuka [Explanatory dictionary of the Russian language]. Moscow: State Publishing house of foreign and national dictionaries. 1940. T. IV. 1501 p. [in Russian].

14. Ukrainska mova za profesiinym spriamuvanniam: pidruchnyk dlia med. HEI [Ukrainian language for professional purposes: a textbook for honey. University]. Kiev. 2017. 360 p. [in Ukrainian].

15. Ukrainska radianska entsyklopediia [Ukrainian Soviet Encyclopedia]. Kyiv. 1959-1965. T. 1-17 [in Ukrainian].

16. Entsyklopedycheskyi slovar [Encyclopedic Dictionary]. Moscow: State. scientific Publishing house «Great Soviet Encyclopedia». 1955. T. 3. 744 p. [in Russian]. 